\title{
A rapid assessment method for determination of iodate in table salt samples
}

\author{
Preeti S Kulkarni ${ }^{*}$, Satish D Dhar ${ }^{2}$ and Sunil D Kulkarni ${ }^{3}$
}

\begin{abstract}
Background: In the present work, a simple and rapid method for determination of iodate is described.

Methods: lodometric reaction between iodate, excess iodide, and acid has been used, and the iodine liberated is allowed to react with variamine blue (VB) dye in the presence of sodium acetate to yield a violet-colored species.

Results: A calibration curve was obtained in the concentration range of 2 to $30 \mu \mathrm{g}$ of iodate in a final equilibration volume of $10 \mathrm{~mL}$. The effect of different interfering anions on determination of iodate was also studied.

Conclusions: The developed method was applied to iodate determination in various iodized salt samples obtained from local markets in and around Pune city, India. The amount of iodate in various table salt samples was in the range of 10 to $25 \mathrm{ppm}$.
\end{abstract}

Keywords: Iodate; Table salt; Variamine blue dye; lodometric reaction; Spectrophotometry

\section{Background}

Iodine is an essential trace element for human nutrition. The safe dietary intake of iodine as recommended by the World Health Organization (WHO) is $100 \mu \mathrm{g} \mathrm{day}^{-1}$ for infants and $150 \mu \mathrm{g} \mathrm{day}^{-1}$ for adults (Hetzel 1983). Iodine is required by the thyroid gland for the synthesis of $T_{3}$ and $\mathrm{T}_{4}$ hormones (Visser 2006). The storehouse of iodine in the human body is the thyroid gland. Inadequate intake of iodine leads to iodine deficiency symptoms and disorders like goiter, extreme fatigue, mental retardation, and depression which are collectively called as iodine deficiency disorders (IDDs). In India, about 71 million people suffer from iodine deficiency disorders. Statistics furnished by the Ministry of Health and Family Welfare in its report revealed that Uttar Pradesh, Bihar, Madhya Pradesh, Maharashtra, and Gujarat states contributing to almost $70 \%$ population have maximum IDD cases.

The natural dietary sources of iodine include milk, vegetables, fruits, cereals, eggs, meat, spinach, and sea foods (Zimmermann 2009). However, natural sources of iodine may not satisfy its requirement by the body as iodine from these sources may not be in bioavailable form and also the concentration of iodine may be less.

\footnotetext{
*Correspondence: bhagatpreeti@gmail.com

'Department of Chemistry, Postgraduate and Research Centre, MES

Abasaheb Garware College, Pune-411005, India

Full list of author information is available at the end of the article
}

Adequate intake of iodine can be achieved by consumption of iodized salt. Iodization of salt is done by addition of iodate to salt samples due to its good stability and bioavailability (Bürgi et al. 2001). Thus, determination of iodate in salt samples is of considerable importance as the amount of iodate in the salt samples may vary with environmental conditions, the nature of transport, packing conditions, and cooking methods (Bruchertseifer et al. 2003).

There are various analytical methods for determination of iodate in seawater and iodized salt samples. Some of the recent methods include kinetic spectrophotometric methods ( $\mathrm{Ni}$ and Wang 2007), flow injection analysis (Shabani et al. 2011), microspectrophotometry after liquidphase microextraction (Pereira et al. 2010), using cadmium sulfide quantum dots as fluorescence probes (Tang et al. 2010), liquid-liquid microextraction by high-performance liquid chromatography-diode array detection (Gupta et al. 2011), ion chromatography with integrated amperometric detection (Babulal et al. 2010), transient isotachophoresiscapillary zone electrophoresis (Wang et al. 2009), gas chromatography-mass spectrometry (Das et al. 2004), using polymer membrane selective for molecular iodine (Bhagat et al. 2008), and neutron activation analysis method (Bhagat et al. 2009). A non-suppressed ion chromatography with inductively coupled mass spectrometry (ICP-MS) has been

\section{实}


developed for the simultaneous determination of iodate and iodide in seawater ( $\mathrm{Zul}$ et al. 2007). Most of the techniques are complex and involve sophisticated instruments and complex procedures. It is also observed that application of these analytical methods for iodate determination in table salt is complicated due to the presence of huge excess of chloride, for example, in the case of anion exchange chromatography with conductometric detection which requires the removal of large excess of chloride from the sample matrix (Kumar et al. 2001). Hence, development of a method that is selective for iodate and sensitive and requires simple and inexpensive experimental setup is of considerable scientific interest. Also, accurate determination of the contribution of iodine from table salt to total dietary intake requires novel methods. With this objective in the present work, a simple and rapid method for determination of iodate is described. Iodometric reaction between iodate, excess iodide, and acid has been used, and the liberated iodine is allowed to react with variamine blue (VB) dye to yield a violet-colored species with absorbance maxima at $550 \mathrm{~nm}$. The developed method was applied to determine the iodate concentration in table salt samples obtained from local markets in and around Pune city in India. The kinetics of the method is very fast, and a large number of table salt samples can be screened for their iodate content in a short time. The iodate content thus determined by the developed method was compared with the iodate content determined by conventional iodometric titration. The method developed in the present work has advantages over conventional methods, for example, it is free from losses of iodine and it is interference free.

\section{Methods}

\section{Apparatus}

A computer-based spectrophotometer (Systronics, Ahmedabad, India) was used for all the absorbance measurements. A pH meter (Labtronics, Panchkula, India) was used to monitor the $\mathrm{pH}$ of the equilibrating solutions. The $\mathrm{pH}$ meter was standardized using $\mathrm{pH} 4,7$, and 10 buffer solutions. A digital balance (Contech, Mumbai, India) was used for weighing all the reagents. Doubledistilled water was used throughout all the work which was prepared using Equitron's instrument (Mumbai, India).

\section{Reagents and solutions}

All reagents used were of analytical reagent grade (A.R. grade) and used without further purification. Variamine blue (Merck, Mumbai, India), potassium iodate (S.M Chemicals, Mumbai, India), potassium iodide (Loba Chemie, Mumbai, India), sodium chloride (Qualigens, Mumbai, India), potassium bromate (Qualigens), ammonium oxalate (Qualigens), potassium chloride (Qualigens), sodium bicarbonate (Qualigens), potassium nitrate (Qualigens), zinc sulfate (Qualigens), methyl alcohol (Qualigens), and magnesium carbonate (Qualigens) were used. A variamine blue dye solution was prepared by dissolving $20 \mathrm{mg}$ of the dye in methyl alcohol and diluting the solution to $50 \mathrm{~mL}$ using distilled water. A potassium iodate solution was prepared by dissolving $0.0122 \mathrm{~g}$ of $\mathrm{KIO}_{3}$ in distilled water and diluting it to $100 \mathrm{~mL}[1 \mathrm{~mL}=100 \mu \mathrm{g} \mathrm{IO}-]$. Sulfuric acid ( $1 \mathrm{M}$ ) was prepared by diluting $6.95 \mathrm{~mL}$ of stock $\mathrm{H}_{2} \mathrm{SO}_{4}$ to the mark in a $250-\mathrm{mL}$ volumetric flask with distilled water. A solution of potassium iodide was prepared by dissolving $25 \mathrm{mg}$ potassium iodide in water and diluting it up to $100 \mathrm{~mL}[1 \mathrm{~mL}=250 \mu \mathrm{g}]$. A solution of sodium acetate (2 M) was prepared by dissolving $13.608 \mathrm{~g}$ of A.R. grade sodium acetate in distilled water and diluting the solution to $100 \mathrm{~mL}$ in a volumetric flask The different interfering ion solutions such as potassium chloride $(\mathrm{KCl})$, sodium bicarbonate $\left(\mathrm{NaHCO}_{3}\right)$, potassium nitrate $\left(\mathrm{KNO}_{3}\right)$, zinc sulfate $\left(\mathrm{ZnSO}_{4}\right)$, potassium bromate $\left(\mathrm{KBrO}_{3}\right)$, etc. were prepared by dissolving and diluting suitable amounts of the respective salts in distilled water to make a concentration of $1 \mathrm{~mL}=100 \mu \mathrm{g}$.

\section{Samples for iodate determination}

A total of 12 different brands of iodized salt samples were analyzed in the present work. The samples were purchased from local markets in and around Pune city. The samples were stored in cool and dry conditions. The contents of the packets were transferred immediately upon opening into an air tight container.

\section{Optimization of parameters for the iodometric reaction}

Various parameters associated with the iodometric reaction were optimized. The amount of potassium iodide and the concentration of acid were optimized in a similar manner as reported in our previous work (Bhagat et al. 2008) The concentration of iodate was fixed as $10 \mu \mathrm{g}$ during the optimization experiments. Experiments were performed to optimize the dye concentration and $\mathrm{pH}$ of the reaction mixture. $\mathrm{pH}$ adjustments were done using either $2 \mathrm{M} \mathrm{NaOH}$ or $2 \mathrm{M} \mathrm{HCl}$. The time required for the completion of the reaction was measured by studying the changes in absorbance as a function of time. The absorbance values were recorded in the intervals of $30 \mathrm{~s}$ till $30 \mathrm{~min}$.

\section{Measurement of iodate in the aqueous solution}

An aliquot of iodate solution containing 2 to $30 \mu \mathrm{g}$ of iodate was taken in $10-\mathrm{mL}$ volumetric flasks. Excess of KI $(250 \mu \mathrm{g})$ was added to each flask followed by $1 \mathrm{~mL}$ of $\mathrm{H}_{2} \mathrm{SO}_{4}(1 \mathrm{M})$. The solution turned yellow due to liberation of iodine. At this stage, $1 \mathrm{~mL}$ of dye solution was added followed by addition of $2 \mathrm{~mL}$ sodium acetate $(2 \mathrm{M})$. The solutions were diluted to $10 \mathrm{~mL}$ with distilled water and kept for $5 \mathrm{~min}$ to allow the reaction to complete. After $5 \mathrm{~min}$, the absorbances of all the solutions were recorded 
at $550 \mathrm{~nm}$ against water as a reagent blank. A calibration plot of absorbance values of VB dye was plotted against the amount of iodate in solution.

\section{Interference studies}

The effect of common interfering anions like $\mathrm{Cl}^{-}, \mathrm{SO}_{4}^{2-}$, $\mathrm{NO}_{3}^{-}, \mathrm{Br}^{-}, \mathrm{PO}_{4}^{3-} \mathrm{HCO}_{3}^{-}, \mathrm{C}_{2} \mathrm{O}_{4}^{2-}$, and $\mathrm{BrO}_{3}^{-}$on determination of iodate by the $\mathrm{VB}$ method was studied by the following procedure. The concentration of iodate in the reaction mixture was kept fixed as $5.72 \times 10^{-8} \mathrm{M}$, and the concentration of interfering anions in the equilibrating solution was varied.

\section{Application to table salt samples}

Before application of the method to table salt samples, it was applied to A.R. grade laboratory reagent $\mathrm{NaCl}$ to study the effect of sodium chloride on the absorbance values. In the case of iodized table salt samples, a homogenous portion of $2 \mathrm{~g}$ of sample was weighed accurately on a balance and dissolved in distilled water. The final volume was made up to $25 \mathrm{~mL}$, and the solution was used for further analysis. The concentration of iodate in the samples was calculated using a calibration curve. Each sample was analyzed five times, and the standard deviation was calculated. The iodate content in these salt samples was also analyzed by conventional iodometric titration using $\mathrm{Na}_{2} \mathrm{~S}_{2} \mathrm{O}_{3}$ with starch as an indicator.

\section{Results and discussion lodometric reaction}

When an oxidizing agent (analyte) is added to excess iodide in an acidic medium to produce iodine which is determined by titration, the method is called iodometry. Iodometry provides a simple and rapid method of analysis. It also provides chemical amplification of signals (Zhang et al. 1998). However, conventional iodometric titrations suffer from several limitations like losses of iodine, titration error, lack of suitable indicators, and poor detection limits. These limitations can be overcome by converting the liberated iodine into an appropriate signal to prevent losses of iodine. Iodate is a good oxidizing reagent, hence oxidizes iodide to iodine in the presence of mineral acid (Pierce and Haenisch 1945). The reaction offers good signal enhancement as it can be seen from reaction 1 that the iodine content in the product side of the reaction is increased three times on a molar basis. This chemical amplification was conveniently used to determine the concentration of iodate in the present work.

$$
\mathrm{IO}_{3}^{-}+5 \mathrm{I}^{-}+6 \mathrm{H}^{+} \rightarrow 3 \mathrm{H}_{2} \mathrm{O}+3 \mathrm{I}_{2} .
$$

This modified iodometric reaction is selective towards iodate, and huge excess of chloride in the table salt samples does not interfere the determination of iodate as chloride cannot oxidize iodide to iodine. The common difficulty with the iodometric reaction for analytical purposes is the trapping of liberated iodine. In this work, the liberated iodine was allowed to react with the VB dye in the presence of sodium acetate (reaction 2). Variamine blue is known to be a suitable chromogenic reagent for iodine (Revansiddapa and Kumar 2001; Narayana and Cherian 2005; Coo and Martinez 2004). The liberated $I_{2}$ oxidizes the dye to a violet color whose absorbance maxima is at $550 \mathrm{~nm}$. The visible spectrum of the oxidized variamine blue dye is shown in Figure 1. The use of this dye offered an advantage of quick reaction kinetics so that complete utilization of liberated iodine is ensured.

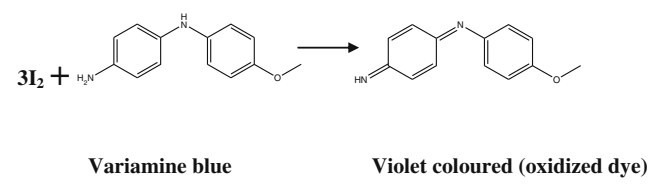

\section{Optimization of parameters for iodometric reaction}

The optimization of different parameters related to the reaction was done. The concentration of the dye was varied in the range of $0.61 \times 10^{-6}$ to $12.2 \times 10^{-6} \mathrm{~mol} \mathrm{~L}^{-1}$. Figure 2 shows the effect of dye concentration on its absorbance. It was observed that the maximum absorbance value was obtained for the dye concentration of $2.44 \times$ $10^{-6} \mathrm{~mol} \mathrm{~L}^{-1}$. However, the absorbance values were lower at dye concentrations below and above this value. This concentration of the dye was used for all further experiments. The amount of iodide was varied between 250 and $1,000 \mu \mathrm{g}$. It was found that $250 \mu \mathrm{g}$ of $\mathrm{I}^{-}$was enough to convert $\mathrm{IO}_{3}^{-}$to $\mathrm{I}_{2}$ quantitatively (Bhagat et al. 2008). The $\mathrm{pH}$ of the reaction mixture was varied between 2.5 and 11. It was found that the maximum absorbance was recorded at $\mathrm{pH} 5$ as the oxidized form of

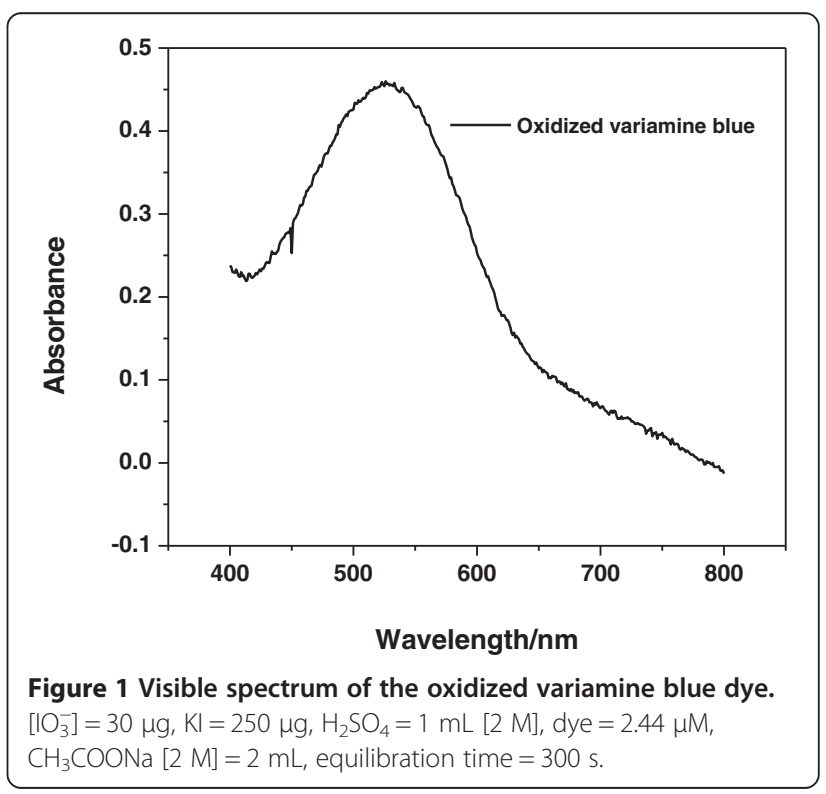




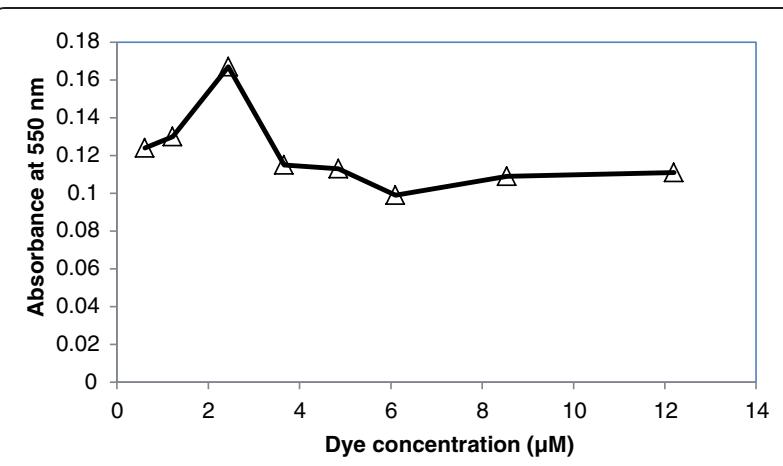

Figure 2 Effect of the concentration of variamine blue dye on absorbance at $550 \mathrm{~nm}$. $\left[\mathrm{IO}_{3}^{-}\right]=10 \mu \mathrm{g}, \mathrm{Kl}=250 \mu \mathrm{g}, \mathrm{H}_{2} \mathrm{SO}_{4}=1 \mathrm{~mL}$ $[2 \mathrm{M}], \mathrm{CH}_{3} \mathrm{COONa}[2 \mathrm{M}]=2 \mathrm{~mL}$, equilibration time $=300 \mathrm{~s}$.

variamine blue is stable at this $\mathrm{pH}$ (Figure 3). The effect of acid concentration on the uptake of iodate was studied by varying the amount of $\mathrm{H}_{2} \mathrm{SO}_{4}(1 \mathrm{M})$. It was found that $1 \mathrm{~mL}$ of $\mathrm{H}_{2} \mathrm{SO}_{4}$ gave maximum absorbance. To study the effect of time on the absorbance of VB dye, all other conditions were kept fixed and the absorbance was recorded at intervals of $30 \mathrm{~s}$ for $30 \mathrm{~min}$. It was found that the time required for completion of the reaction was $300 \mathrm{~s}$, after which the absorbance values remained constant (Figure 4). The optimized parameters in the method are given in Table 1.

\section{Calibration curve and detection limits for iodate determination}

The quantitative determination of iodate in aqueous solutions was done by constructing a calibration plot. The reaction was carried out using an iodate amount in the range of 2 to $30 \mu \mathrm{g}$ in a final volume of $10 \mathrm{~mL}$. Then addition of excess iodide was done followed by addition of acid, VB, and sodium acetate in that sequence. The absorbance values of the solutions were plotted as a

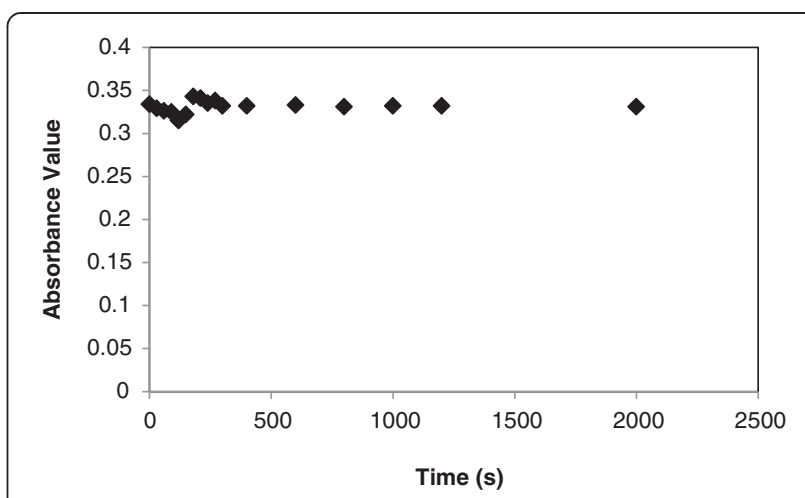

Figure 4 Absorbance of variamine blue dye as a function of the time of reaction. $\left[\mathrm{IO}_{3}^{-}\right]=10 \mu \mathrm{g}, \mathrm{Kl}=250 \mu \mathrm{g}, \mathrm{H}_{2} \mathrm{SO}_{4}=1 \mathrm{~mL}[2 \mathrm{M}]$, dye $=2.44 \mu \mathrm{M}, \mathrm{CH}_{3} \mathrm{COONa}[2 \mathrm{M}]=2 \mathrm{~mL}$.

function of the iodate amount in the solutions and used as a calibration plot (Figure 5) for further quantifications. The plot was found to be linear till $30 \mu \mathrm{g}$ of iodate. The regression value obtained for the calibration plot is 0.987 , and the equation of the calibration plot calculated using 15 standards in the range of 2 to $30 \mu \mathrm{g}$ in a final volume of $10 \mathrm{~mL}$ is $y=0.013 x$. A good linear relationship between absorbance values and amount of iodate suggests the use of the present method for quantitative determination of iodate in aqueous samples. The detection limit of the method is $0.25 \mu \mathrm{g}$, calculated using the relation $\mathrm{DL}=3 s / S$, where $s$ is the standard deviation of the reagent blank and $S$ is the slope of the calibration curve.

\section{Effect of interfering anions on determination of iodate}

The effect of interfering anions on determination of iodate in aqueous samples like $\mathrm{Cl}^{-}, \mathrm{SO}_{4}^{2-}, \mathrm{NO}_{3}^{-}, \mathrm{Br}^{-}, \mathrm{PO}_{4}^{3-}$, $\mathrm{HCO}_{3}^{-}, \mathrm{C}_{2} \mathrm{O}_{4}^{2-}$, and $\mathrm{BrO}_{3}^{-}$was studied. The amount of iodate in aqueous samples was kept as $5.72 \times 10^{-8} \mathrm{M}$,

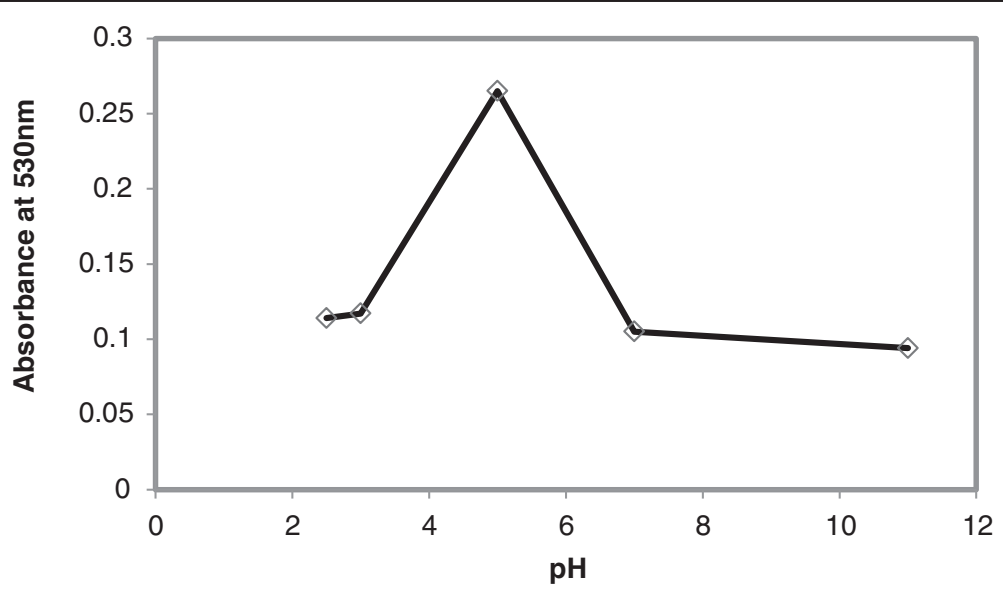

Figure 3 Effect of the $\mathrm{pH}$ of reaction mixture on the absorbance value. $\left[\mathrm{IO}_{3}^{-}\right]=10 \mu \mathrm{g}, \mathrm{Kl}=250 \mu \mathrm{g}, \mathrm{H}_{2} \mathrm{SO}_{4}=1 \mathrm{~mL}[2 \mathrm{M}], \mathrm{dye}=2.44 \mu \mathrm{M}$, $\mathrm{CH}_{3} \mathrm{COONa}[2 \mathrm{M}]=2 \mathrm{~mL}$, equilibration time $=300 \mathrm{~s}$. 


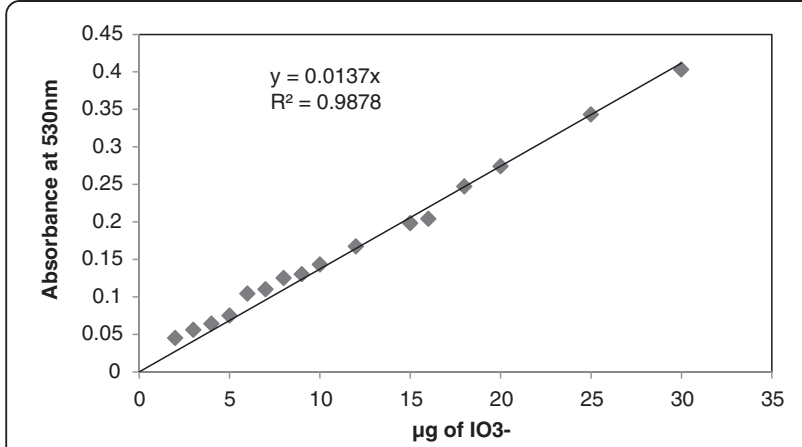

Figure 5 Calibration curve of iodate. $\left[\mathrm{IO}_{3}^{-}\right]=2$ to $30 \mu \mathrm{g}, \mathrm{Kl}=$ $250 \mu \mathrm{g}, \mathrm{H}_{2} \mathrm{SO}_{4}=1 \mathrm{~mL}[2 \mathrm{M}]$, dye $=2.44 \mu \mathrm{M}, \mathrm{CH}_{3} \mathrm{COONa}[2 \mathrm{M}]=$ $2 \mathrm{~mL}$, equilibration time $=300 \mathrm{~s}$.

and the amount of interfering anions in the equilibrating solution was varied. The uptake of $\mathrm{IO}_{3}^{-}$in the presence of excess of anions likely to be encountered in the food samples and other aqueous samples was calculated by measuring the absorbance of $\mathrm{VB}$ in the solution as a function of the ratio $\left[X^{-}\right] /\left[\mathrm{IO}_{3}^{-}\right]$, where $\left[X^{-}\right]$is the concentration of the interfering anion. The tolerance limits of various anions are given in Table 2 .

\section{Determination of iodate in iodized salt samples}

Fortification of table salt is done with $\mathrm{KIO}_{3}$ in order to meet the requirements of iodine in human beings. Iodate is added in the range of 15 to $50 \mathrm{ppm}$ to table salt. Various brands of iodized salt samples were subjected to the method described above for determination of iodate content. Before analyzing the iodized salt samples, the protocol was used for iodate determination in A.R. grade $\mathrm{NaCl}$ (lab reagent), and it was found that there was no effect of $\mathrm{NaCl}$ on the absorbance of $\mathrm{VB}$. Consequently, the analysis method was applied to various iodized salt brands. The iodate concentrations obtained in these samples are given in Table 3. It is found that the iodate content was found to be in the range of 10 to $22 \mathrm{ppm}$. A set of five measurements were carried out for each sample, and the mean values are reported along with standard deviations. The standard deviation is in the range of 0.40 to 3.8 . Brand number 3 and 5 showed less values of

Table 1 Optimized parameters used for analysis

\begin{tabular}{lcc}
\hline Serial number & Optimized parameters & Value \\
\hline 1 & $\mathrm{IO}_{3}^{-}$ & $2 \mathrm{to} 30 \mu \mathrm{g}$ \\
2 & $\mathrm{KI}$ & $250 \mu \mathrm{g}$ \\
3 & $\mathrm{H}_{2} \mathrm{SO}_{4}$ & $1 \mathrm{~mL}[2 \mathrm{M}]$ \\
4 & $\mathrm{pH}$ & 5.0 \\
5 & Dye & $2.44 \mu \mathrm{M}$ \\
6 & Sodium acetate & $2 \mathrm{~mL} \mathrm{of} 2 \mathrm{M}$ \\
7 & Time & $300 \mathrm{~s}$ \\
\hline
\end{tabular}

Table 2 Effect of some interfering anions on iodate determination

\begin{tabular}{lcc}
\hline Serial number & Interfering anion $\left[X^{-}\right]$ & Tolerated ratio $\left[X^{-}\right] /\left[\mathrm{IO}_{3}^{-}\right]$ \\
\hline 1 & $\mathrm{Cl}^{-}$ & 500 \\
2 & $\mathrm{NO}_{3}^{-}$ & 100 \\
3 & $\mathrm{SO}_{4}^{2-}$ & 50 \\
4 & $\mathrm{Br}^{-}$ & 50 \\
5 & $\mathrm{PO}_{4}^{3-}$ & 50 \\
6 & $\mathrm{HCO}_{3}^{-}$ & 5 \\
7 & $\mathrm{C}_{2} \mathrm{O}_{4}^{2-}$ & 25 \\
8 & $\mathrm{BrO}_{3}^{-}$ & 5 \\
\hline
\end{tabular}

iodate as compared to the quoted value when analyzed by this method. The iodine content as quoted by the manufacturer is also given in Table 3. The amount of iodine obtained by conventional iodometric titration is also given in the table.

According to WHO, the daily dietary intake of iodine is $150 \mu \mathrm{g}$ for adults. Considering the spicy food habits in India, the average intake of salt through food may be in the range of 2 to $3 \mathrm{~g}$ per day. Using this approximation, the contribution of iodine from table salt can be calculated to be around 30 to $40 \mu \mathrm{g}$ per day. The bioavailability of iodine may be considered to be $100 \%$ due to its solubility in digestive fluids. The contribution of iodine from table salt is estimated to be $20 \%$ to $40 \%$ of the total iodine requirement. This contribution may not be enough in regions where the soil is deficient in iodine content. Consequently, iodine deficiency disorders will be prevalent in these regions.

Table 3 lodate values obtained in local brands of table salt

\begin{tabular}{lccc}
\hline $\begin{array}{l}\text { Serial } \\
\text { number }\end{array}$ & $\begin{array}{c}\text { Brand } \\
\text { name }\end{array}$ & $\begin{array}{c}\text { lodate }(\mathbf{p p m}) \pm \text { SD } \\
(\boldsymbol{n}=\mathbf{3})\end{array}$ & $\begin{array}{c}\text { lodate }(\mathbf{p p m}) \pm \text { SD } \\
(\boldsymbol{n}=\mathbf{3})\end{array}$ \\
\hline 1 & Brand 1 & $15.31 \pm 2.645$ & $14.3 \pm 0.2$ \\
by variamine blue method & iodometry \\
2 & Brand 2 & $14.67 \pm 2.336$ & $13.6 \pm 0.1$ \\
3 & Brand 3 & $11.83 \pm 1.98$ & $10.8 \pm 0.2$ \\
4 & Brand 4 & $15.76 \pm 3.80$ & $16.3 \pm 0.1$ \\
5 & Brand 5 & $10.78 \pm 0.46$ & $9.8 \pm 0.1$ \\
6 & Brand 6 & $15.22 \pm 1.90$ & $15.5 \pm 0.2$ \\
7 & Brand 7 & $16.01 \pm 1.46$ & $14.3 \pm 0.1$ \\
8 & Brand 8 & $21.09 \pm 2.50$ & $23.2 \pm 0.1$ \\
9 & Brand 9 & $16.02 \pm 0.48$ & $15.6 \pm 0.2$ \\
10 & Brand 10 & $16.20 \pm 0.56$ & $15.9 \pm 0.1$ \\
11 & Brand 11 & $18.20 \pm 0.66$ & $19.3 \pm 0.2$ \\
12 & Brand 12 & $17.60 \pm 2.34$ & $18.5 \pm 0.2$ \\
\hline
\end{tabular}




\section{Conclusions}

A simple and rapid method has been developed for determination of iodate in aqueous samples. The method is applicable to iodate determination in the concentration range of 2 to $30 \mu \mathrm{g}$ in a final equilibration volume of $10 \mathrm{~mL}$. Optimized parameters for the method are $\mathrm{IO}_{3}^{-}$ (2 to $30 \mu \mathrm{g})$, KI $(250 \mu \mathrm{g}), 2 \mathrm{M} \mathrm{H}_{2} \mathrm{SO}_{4}(1 \mathrm{~mL}), \mathrm{pH}$ (5.0), time of equilibration (20 $\mathrm{min}), 2.44 \mu \mathrm{M}$ dye $(20 \mu \mathrm{g}$, $1 \mathrm{~mL}$ ), and $2 \mathrm{~mL}$ sodium acetate $(2 \mathrm{M})$. The concentration of $\mathrm{IO}_{3}^{-}$obtained in the salt samples was in the range of 10 to $22 \mathrm{ppm}$. The results obtained by the present method are in good agreement with those obtained by conventional iodometry, thus validating the method.

\section{Competing interests}

Authors declare that there are no competing interests.

\section{Authors' contributions}

PSK: Original idea, design of work, SDD: Execution of experiments, SDK: Data interpretation and manuscript writing. All authors read and approved the final manuscript.

\section{Author details}

${ }^{1}$ Department of Chemistry, Postgraduate and Research Centre, MES Abasaheb Garware College, Pune-411005, India. ${ }^{2}$ Modern College, Shivajinagar, Pune 411005, India. ${ }^{3}$ Department of Chemistry, Sir

Parashurambhau, Pune-411030, India.

Received: 20 June 2013 Accepted: 18 October 2013

Published: 15 Nov 2013

\section{References}

Babulal R, Parimal P, Ghosh PK (2010) Determination of iodide and iodate in edible salt by ion chromatography with integrated amperometric detection. Food Chem 123:529-534

Bhagat PR, Pandey AK, Acharya R, Natarajan V, Rajurkar NS, Reddy AVR (2008) Molecular iodine selective membrane for iodate determination in salt samples: chemical amplification and preconcentration. Anal Bioanal Chem 391:1081-1089

Bhagat PR, Acharya R, Nair AGC, Pandey AK, Rajurkar NS, Reddy AVR (2009) Estimation of iodine in food, food products and salt using ENAA. Food Chem 115:706-710

Bruchertseifer H, Cripps R, Guentay S, Jaeckel B (2003) Analysis of iodine species in aqueous solutions. Anal Bioanal Chem 375:1107-1110

Bürgi H, Schaffner T, Seiler JP (2001) The toxicology of iodate: a review of the literature. Thyroid 11:449-456

Coo LD, Martinez IS (2004) Nafion-based optical sensor for the determination of selenium in water samples. Talanta 64:1317-1322

Das P, Gupta M, Jain A, Verma KK (2004) Single drop microextraction or solid phase microextraction-gas chromatography-mass spectrometry for the determination of iodine in pharmaceuticals, iodized salt, milk powder and vegetables involving conversion into 4-iodo-N,N-dimethylaniline. J Chromatogr A 1023:33-39

Gupta M, Pillai AKKV, Singh A, Jain A, Verma KK (2011) Salt assisted liquid-liquid microextraction for the determination of iodine in table salt by high-performance liquid chromatography-diode array detection. Food Chem 124:1741-1746

Hetzel BS (1983) lodine deficiency disorders (IDD) and their eradication. Lancet 2:1126-1127

Kumar SD, Maiti B, Mathur PK (2001) Determination of iodate and sulphate in iodized table salt by ion chromatography with conductivity detection. Talanta 53:701-705

Narayana B, Cherian T (2005) Rapid spectrophotometric determination of trace amounts of chromium using variamine blue as a chromogenic reagent. J Brazil Chem Soc 16:197-201
Ni Y, Wang Y (2007) Application of chemometric methods to the simultaneous kinetic spectrophotometric determination of iodate and periodate based on consecutive reactions. Microchem J 86:216-226

Pereira FP, Ferreiro SS, Lavilla I, Bendicho C (2010) Determination of iodate in waters by cuvetteless UV-vis micro-spectrophotometry after liquid-phase microextraction. Talanta 81:625-629

Pierce WC, Haenisch EL (1945) Quantitative analysis, 2nd edition. Wiley, New York, pp 199-216

Revansiddapa H, Kumar TLK (2001) A facile spectrophotometric method for the determination of selenium. Anal Sci 17:1309-1312

Shabani AMH, Ellis PS, McKelvie ID (2011) Spectrophotometric determination of iodate in iodised salt by flow injection analysis. Food Chem 129:704-707

Tang CR, Su Z, Lin B, Huang H, Zeng Y, Li S, Huang H, Wang Y, Li C, Shen G, Yu R (2010) A novel method for iodate determination using cadmium sulfide quantum dots as fluorescence probes. Anal Chim Acta 678:203-207

Visser TJ (2006) The elemental importance of sufficient iodine intake: a trace is not enough. Endocrinol 147:2095-2097

Wang T, Zhao S, Shen C, Tang J, Wang D (2009) Determination of iodate in table salt by transient isotachophoresis-capillary zone electrophoresis. Food Chem $112: 215-220$

Zhang M, Zhan G, Chen Z (1998) lodometric amplification methods for the determinations of microgram amounts of manganese (II), manganese (VII), chromium (III) and chromium (VI) in aqueous solution. Anal Sci 14:1077-1083

Zimmermann MB (2009) lodine deficiency. Endocrine Rev 30:376-408

Zul C, Megharaj M, Naidu R (2007) Speciation of iodate and iodide in seawater by non-suppressed ion chromatography with inductively coupled plasma mass spectrometry. Talanta 72:1842-1846

10.1186/2093-3371-4-21

Cite this article as: Kulkarni et al:: A rapid assessment method for determination of iodate in table salt samples. Journal of Analytical Science and Technology 2013, 4:21

\section{Submit your manuscript to a SpringerOpen ${ }^{\odot}$ journal and benefit from:}

- Convenient online submission

- Rigorous peer review

- Immediate publication on acceptance

- Open access: articles freely available online

- High visibility within the field

- Retaining the copyright to your article

Submit your next manuscript at $>$ springeropen.com 